\title{
Nesiotobacter exalbescens gen. nov., sp. nov., a moderately thermophilic alphaproteobacterium from an Hawaiian hypersaline lake
}

Correspondence
Maqsudul Alam
alam@hawaii.edu
Water collected from the hypersaline lagoon at the centre of uninhabited Laysan $\left(25^{\circ} 46^{\prime} \mathrm{N} 171^{\circ} 44^{\prime} \mathrm{W}\right)$ in the Northwestern Hawaiian Islands was spread on ASP medium, a minimal medium containing $\left(1^{-1}\right) 1 \mathrm{~g}$ aspartic acid (monosodium salt), $10 \mathrm{~g}$ glycerol, $1 \mathrm{~g} \mathrm{~K}_{2} \mathrm{HPO}_{4}, 15 \mathrm{~g}$ agar, $40 \mathrm{~g} \mathrm{NaCl}$ and $1 \mathrm{ml} \mathrm{SL}-8$ micronutrient solution (Atlas, 1997). After incubation in darkness $\left(25^{\circ} \mathrm{C}, 7\right.$ days $)$, representative colonies were transferred to marine agar $2216 \mathrm{E}$ (MA; Difco) and incubated at $30^{\circ} \mathrm{C}$ (Donachie et al., 2004a). Strain LA33B ${ }^{\mathrm{T}}$ grew as off-white, $1-2 \mathrm{~mm}$, translucent colonies. Working cultures were maintained on MA. Stock cultures were stored at $-80^{\circ} \mathrm{C}$ in marine broth (MB; Difco) and glycerol $(30 \% \mathrm{w} / \mathrm{v})$.

Tolerance of $\mathrm{NaCl}$ was tested on tryptic soy agar (TSA; BBL) containing $0 \cdot 5-20 \%(\mathrm{w} / \mathrm{v}) \mathrm{NaCl}$ at $30{ }^{\circ} \mathrm{C}$ for 10 days and in $50 \% \mathrm{MB}$ with $1-20 \% \mathrm{NaCl}(\mathrm{w} / \mathrm{v}) ; 50 \% \mathrm{MB}$ is half-strength $\mathrm{MB}$ prepared with distilled water and supplemented with

The GenBank/EMBL/DDBJ accession number for the 16S rRNA gene sequence of Nesiotobacter exalbescens LA33B $^{\top}$ is AF513441.

A scanning electron micrograph of Nesiotobacter exalbescens cells, growth curves in relation to salinity and a fatty acid profile of whole cells are available as supplementary material in IJSEM Online.
$\mathrm{NaCl}$ in a range from 1 to $20 \%$ (w/v). Growth was followed for $131 \mathrm{~h}$ by measuring turbidity at $600 \mathrm{~nm}$ in a spectrophotometer (DU 650; Beckman). The temperature range for growth was tested on MA from 4 to $58^{\circ} \mathrm{C}$. Motility was determined in a hanging drop under a $100 \times$ objective with oil immersion. Microaerophilic growth on MA was checked in the GasPak Pouch system (BBL) with oxygen and carbon dioxide concentrations of $<2$ and $>4 \%$, respectively. Cells grown for $72 \mathrm{~h}$ in $\mathrm{MB}$ were prepared for scanning electron microscopy (Donachie et al., 2002).

Single colonies of $\mathrm{LA}_{3} 3 \mathrm{~B}^{\mathrm{T}}$ on MA were tested for catalase and cytochrome oxidase $c$ activities with $3 \%(\mathrm{v} / \mathrm{v})$ hydrogen peroxide (Sigma) and $1 \%$ tetramethyl-p-phenylenediamine on paper discs (BBL), respectively. Nitrate reduction was determined in nitrate broth (Difco) containing $\mathrm{NaCl}$ to $7 \cdot 5 \%(\mathrm{w} / \mathrm{v})$ with standard reagents added after $48 \mathrm{~h}$ at $30^{\circ} \mathrm{C}$ and in API 20NE tests supplemented with $2 \%(\mathrm{w} / \mathrm{v}) \mathrm{NaCl}$ (bioMérieux). Amylase activity, constitutive enzyme activities (API ZYM) and oxidation of single carbon sources (Biolog GN) were tested as described previously (Donachie et al., 2004b). Growth on, and acidification of, single carbohydrates were tested in API $50 \mathrm{CHB} / \mathrm{E}$ medium (bioMérieux), with the salinity of the medium adjusted to 
$2 \%(\mathrm{w} / \mathrm{v})$ by the addition of sterile $20 \%(\mathrm{w} / \mathrm{v}) \mathrm{NaCl}$. Absorption spectra of cells grown aerobically on MA at $30^{\circ} \mathrm{C}$ for $48 \mathrm{~h}$ and suspended in $60 \%$ sucrose (in distilled water) and of the same cells extracted with methanol (overnight, $4{ }^{\circ} \mathrm{C}$ ) were determined between 400 and $900 \mathrm{~nm}$ in a spectrophotometer (DU 650; Beckman) (Nishimura et al., 1994; Uchino et al., 1998). Manganese oxidation was tested on medium K (Rosson \& Nealson, 1982). Fatty acids in cells grown on $\mathrm{MA}$ at $30{ }^{\circ} \mathrm{C}$ were determined commercially (Sasser, 1997).

Genomic DNA was extracted from a $72 \mathrm{~h}$ culture in $\mathrm{MB}$ (Marmur, 1961; Donachie et al., 2004a) and a fragment of the $16 \mathrm{~S}$ rRNA gene was amplified by PCR with Pfu DNA polymerase and primers 27F and 1492R (Lane, 1991; Donachie et al., 2004b). A consensus of sequences, manually edited and assembled in SEQMAN (Lasergene), was compared with those in the public domain through a BLAST $n$ search (Altschul et al., 1997). The phylogenetic relationship of LA33B ${ }^{\mathrm{T}}$ with type strains from related genera was viewed in a phylogenetic tree based on a neighbour-joining alignment of their 16S rRNA gene sequences (Saitou \& Nei, 1987) and corrected for multiple substitutions. DNA G $+\mathrm{C}$ content was determined after Mesbah et al. (1989). Genomic DNA was hybridized with that from Stappia aggregata NCIMB $2208^{\mathrm{T}}$ and Roseibium denhamense JCM $10543^{\mathrm{T}}$ (Donachie et al., 2004b).

Morphological and physiological characteristics of strain LA33B $\mathrm{B}^{\mathrm{T}}$ are given in the species description and Table 1. Additionally, the intensity of a pink pigment secreted into the medium fades with time. Cells are single, straight rods (see Supplementary Fig. S1 in IJSEM Online). Optimal salinity for growth in $50 \% \mathrm{MB}$ is $1-2 \%(\mathrm{w} / \mathrm{v}) \mathrm{NaCl}$, but growth occurs at up to $17.5 \%(\mathrm{w} / \mathrm{v}) \mathrm{NaCl}$ after $\sim 80 \mathrm{~h}$ (see Supplementary Fig. S2 in IJSEM Online). In this respect, strain $\mathrm{LA} 33 \mathrm{~B}^{\mathrm{T}}$ is well suited to survival in the hypersaline lagoon from which it was isolated, where salinity has been reported to vary between 40 and 150\%o (Warner, 1963; Maciolek, 1982; Donachie et al., 2004a). Growth also occurs on MA at $45^{\circ} \mathrm{C}$. Colonies develop slowly in a $\mathrm{CO}_{2}$-enriched atmosphere. In nitrate reduction broth, nitrate is not reduced to nitrogen in the absence of $\mathrm{NaCl}$ or in the presence of $3 \cdot 2 \%(\mathrm{w} / \mathrm{v}) \mathrm{NaCl}$, but reduction does proceed in the presence of $7 \cdot 5 \%(\mathrm{w} / \mathrm{v}) \mathrm{NaCl}$. In API 20NE, however, $\mathrm{LA} 33 \mathrm{~B}^{\mathrm{T}}$ reduced nitrate to nitrogen in the presence of $2 \%$ $(\mathrm{w} / \mathrm{v}) \mathrm{NaCl}$. Amylase was not detected.

Over $99 \%$ of the fatty acids in whole cells were named, including cis-11-octadecenoic acid $(18: 1 \omega 7 c, 77 \cdot 72 \%)$, hexadecanoic acid $(16: 0,5 \cdot 29 \%)$ and octadecanoic acid $(18: 0,5 \cdot 22 \%)$. Several other fatty acids each comprised less than $5 \%$ of the total (see Supplementary Table S1 in IJSEM Online). Diverse carbon sources are oxidized in the Biolog GN, namely dextrin, glycogen, sucrose, D-fructose, maltose, D-mannose, $\alpha$-D-glucose, trehalose, turanose, $N$-acetylglucosamine, glucuronamide, $\alpha$-ketoglutaric acid, $\beta$-hydroxybutyric acid, acetic acid, DL-lactic acid, D-galactonic acid lactone, D-galacturonic acid, D-glucuronic acid, L-glutamic acid, L-pyroglutamic acid, p-hydroxyphenylacetic acid, D-gluconic acid, propionic acid, pyruvic acid methyl ester, succinic acid monomethyl ester, inosine, thymidine, uridine, L-alaninamide, L-phenylalanine, L-proline, L-serine, Tween 40 and Tween 80 . Oxidation of D-psicose, D-serine and methyl $\beta$-D-glucoside is weak. Substrate use that differentiates strain LA33B ${ }^{\mathrm{T}}$ from closely related genera is shown in Table 1. Acid production from carbohydrates in API $50 \mathrm{CHB} / \mathrm{E}$ is given in the species description; acid production from sucrose, maltose and D-xylose is weak. The strain also grows weakly in API $50 \mathrm{CHB} / \mathrm{E}$ on D-mannose and gluconate, but these substrates are also oxidized, along with ribose, D-glucose, D-fructose, methyl $\alpha$-D-glucoside and $N$ acetylglucosamine. Constitutive enzyme activities detected in API ZYM are given in the species description. No absorption peaks were determined in whole cells in sucrose or in methanol extracts, suggesting that photopigments are absent. Brown colonies on medium $\mathrm{K}$ are indicative of manganese oxidation.

The $16 \mathrm{~S}$ rRNA gene sequence of strain $\mathrm{LA}_{3} 3 \mathrm{~B}^{\mathrm{T}}$ falls within the $\alpha-2$ subclass of the Proteobacteria, with the closest described neighbours being S. aggregata NCIMB $2208^{\mathrm{T}}$ and $R$. denhamense JCM $10543^{\mathrm{T}}$, which share $94 \cdot 2 \%$ sequence similarity over 1384 nucleotides and $95 \%$ over 1363 nucleotides, respectively (Fig. 1). Hybridization of strain LA33B ${ }^{\mathrm{T}}$ DNA with that of $S$. agrregata NCIMB $2208^{\mathrm{T}}$ and $R$. denhamense JCM $10543^{\mathrm{T}}$ showed 15 and $14 \%$ reassociation, respectively. Strain $\mathrm{LA}_{3} 3 \mathrm{~B}^{\mathrm{T}}$ cannot be considered to belong to either of these species when the recommendation of the ad hoc committee is considered (Wayne et al., 1987). Although the DNA G $+\mathrm{C}$ content and major fatty acid of $R$. denhamense JCM $10543^{\mathrm{T}}$ and strain $\mathrm{LA} 33 \mathrm{~B}^{\mathrm{T}}$ are similar (Suzuki et al., 2000), these strains can be differentiated based on their degree of DNA-DNA reassociation, their maximum growth temperatures and their tolerance of $\mathrm{NaCl}$ (Table 1). Neither type strain of the two Roseibium species grows in the presence of $13.5 \%(\mathrm{w} / \mathrm{v}) \mathrm{NaCl}$ (Suzuki et al., 2000). Strain LA33B ${ }^{\mathrm{T}}$ can also be distinguished from $S$. aggregata by the degree of DNA-DNA reassociation, different pigmentation and the fact that $S$. aggregata does not grow at $45{ }^{\circ} \mathrm{C}$. Phenotypic characteristics of particular value in differentiating LA33 $\mathrm{B}^{\mathrm{T}}$ from members of these and related genera are growth at elevated temperatures, response to salinity, oxidation of substrates in Biolog GN, reduction of nitrate to nitrogen, absence of $\beta$-galactosidase (ONPG) and inability to oxidize D-galactose, gentiobiose, D-mannitol or glycerol (Table 1). We propose that $\mathrm{LA} 33 \mathrm{~B}^{\mathrm{T}}$ is the type strain of the type species of a new genus, Nesiotobacter gen. nov., and propose the name Nesiotobacter exalbescens gen. nov., sp. nov.

\section{Description of Nesiotobacter gen. nov.}

Nesiotobacter (Ne.si'o.to.bac'ter. Gr. adj. nesiotes of an island, insular; N.L. masc. n. bacter from Gr. n. bakterion rod; N.L. masc. n. Nesiotobacter rod from an island, in this case Laysan). 
Table 1. Phenotypic data that differentiate Nesiotobacter exalbescens $L A 33 B^{\top}$ from phylogenetically related species

Species: 1, Nesiotobacter exalbescens LA33B ${ }^{\mathrm{T}}$; 2, Roseibium denhamense JCM $10543^{\mathrm{T}}$ (data from Nishimura et al., 1994; Suzuki et al., 2000; this study); 3 , Roseibium hamelinense CIP $107048^{\mathrm{T}}$ (Nishimura et al., 1994; Suzuki et al., 2000; this study); 4, Stappia stellulata CIP 105977 ${ }^{\mathrm{T}}$ (Uchino et al., 1998; this study); 5, Stappia aggregata NCIMB 2208 ${ }^{\mathrm{T}}$ (Rüger \& Höfle, 1992; Uchino et al., 1998; this study); 6, Rhodobium orientis JCM 9337 (Hiraishi et al., 1995); 7, Phyllobacterium myrsinacearum ATCC 43590 (Lambert et al., 1990; Swings et al., 1992;

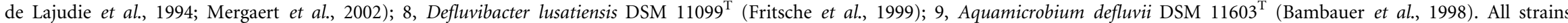
are motile. Results refer to the type strain only in most cases. Characteristics of particular value in differentiating strain LA33B ${ }^{\mathrm{T}}$ from members of related genera are no growth in the absence of $\mathrm{NaCl}$, but growth in the presence of 10 or $13.5 \%(\mathrm{w} / \mathrm{v}) \mathrm{NaCl}$, growth at $45^{\circ} \mathrm{C}$, reduction of $\mathrm{NO}_{2}^{-}$to $\mathrm{N}_{2}$, inability to hydrolyse urea and lack of indole production in $\mathrm{API}$ $20 \mathrm{NE}$ and $20 \mathrm{E}$ tests and oxidation of Tween 80, but not of L-arabinose, D-cellobiose, D-galactose, gentiobiose, D-mannitol or glycerol in Biolog GN tests. Empty cells indicate that no data are available. (+), Weak to no growth; W, weak; v, variable (includes data reported in Rüger \& Höfle, 1992; Uchino et al., 1998; Suzuki et al., 2000).

\begin{tabular}{|c|c|c|c|c|c|c|c|c|c|}
\hline Characteristic & 1 & 2 & 3 & 4 & 5 & 6 & 7 & 8 & 9 \\
\hline Colour ${ }^{\star}$ & $\mathrm{B}$ to $\mathrm{Wh}$ & $\mathrm{P}$ & $\mathrm{P}$ & B & $\mathrm{C}, \mathrm{B}, \mathrm{Y}$ & $\mathrm{P}, \mathrm{R}, \mathrm{C}$ & $\mathrm{C}$ to $\mathrm{B}$ & WhG & W \\
\hline Cell size $(\mu \mathrm{m})$ & $0 \cdot 4-0 \cdot 6 \times 1 \cdot 2-4$ & $0 \cdot 5-0 \cdot 8 \times 1-4$ & $0 \cdot 5-0 \cdot 8 \times 1-4$ & $0 \cdot 6-1 \times 2-4$ & $0 \cdot 6-1 \cdot 2 \times 1-4$ & $0 \cdot 7-0 \cdot 9 \times 1 \cdot 5-3 \cdot 2$ & $0 \cdot 4-0 \cdot 8 \times 0 \cdot 4-1 \cdot 4$ & $0 \cdot 6-0 \cdot 8 \times 1 \cdot 4-3$ & $0 \cdot 5-0.8 \times 1 \cdot 5-2 \cdot 5$ \\
\hline \multicolumn{10}{|l|}{ Growth in $\mathrm{NaCl}(\% \mathrm{w} / \mathrm{v})$ : } \\
\hline 0 & - & - & + & $(+)$ & $(+)$ & & & & \\
\hline 1 & + & + & + & + & + & - & & & + \\
\hline 5 & + & + & + & + & + & + & & & - \\
\hline 10 & + & + & + & - & - & - & & & - \\
\hline $13 \cdot 5$ & + & - & - & - & - & - & & & - \\
\hline \multicolumn{10}{|l|}{ Growth at: } \\
\hline $35^{\circ} \mathrm{C}$ & + & + & + & + & + & & + & + & + \\
\hline $40^{\circ} \mathrm{C}$ & + & - & - & - & - & & - & + & + \\
\hline $45^{\circ} \mathrm{C}$ & + & - & - & - & - & & - & - & - \\
\hline Anaerobic growth & + & - & - & - & $(+)$ & & & & + \\
\hline Bacteriochlorophyll $a$ & - & + & & & & + & & & \\
\hline $\mathrm{NO}_{3}^{-}$to $\mathrm{NO}_{2}^{-} \dagger$ & + & + & + & - & $\mathrm{V}$ & + & + & - & + \\
\hline $\mathrm{NO}_{2}^{-}$to $\mathrm{N}_{2} \dagger$ & + & - & - & + & + & + & + & - & - \\
\hline \multicolumn{10}{|l|}{ Hydrolysis of: } \\
\hline Gelatin $\dagger$ & + & V & $\mathrm{V}$ & - & - & & & & \\
\hline Starch & - & - & - & - & - & & & & \\
\hline Tween 80 & + & $\mathrm{V}$ & $\mathrm{V}$ & & & & - & & \\
\hline Urea $\dagger$ & - & + & - & - & - & & & & \\
\hline $\mathrm{ONPG}^{\dagger}$ & - & + & + & + & + & & & & \\
\hline Indole $\dagger$ & - & + & + & - & - & & & & \\
\hline VP test $\dagger$ & - & - & - & - & - & & & & \\
\hline \multicolumn{10}{|c|}{ Carbon substrate tests (Biolog GN system): } \\
\hline Acid from D-glucose $\ddagger$ & + & + & + & + & $+1-$ & & - & & $\mathrm{W}$ \\
\hline Adonitol & - & - & - & + & - & & + & + & \\
\hline D-Arabitol & - & - & - & - & - & & + & - & \\
\hline L-Arabinose & - & - & - & + & + & - & $+1-$ & - & \\
\hline D-Cellobiose & - & + & - & + & + & & + & - & \\
\hline D-Galactose & - & + & + & + & + & + & + & - & - \\
\hline
\end{tabular}




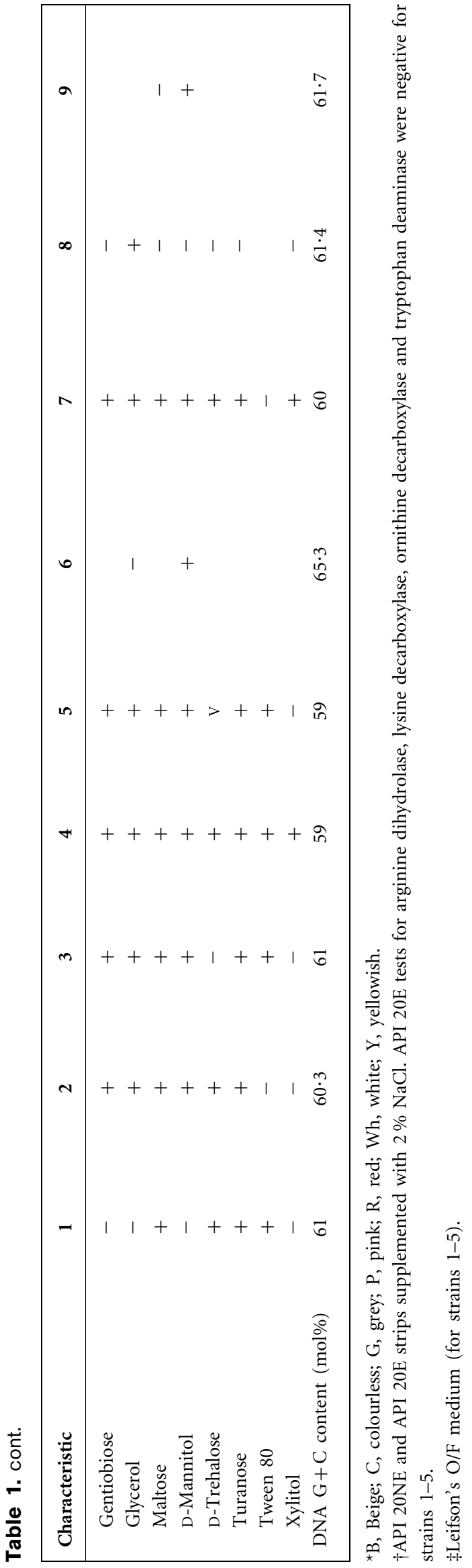

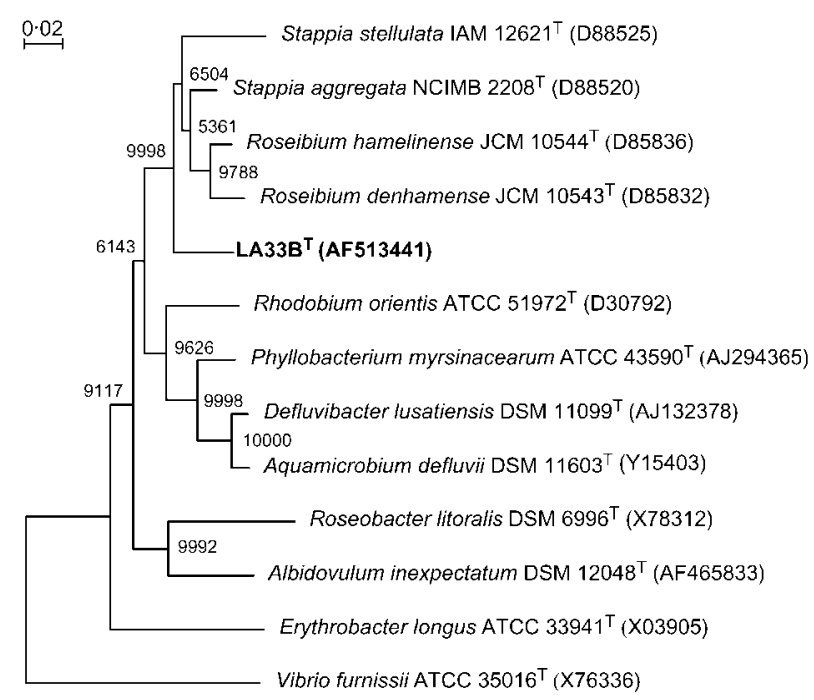

Fig. 1. Phylogenetic tree showing the relationship of Nesiotobacter exalbescens $\mathrm{LA} 3 \mathrm{~B}^{\top}$ to representatives of the Alphaproteobacteria, on the basis of 1363 nucleotides from the $16 \mathrm{~S}$ rRNA gene sequence. Sequences were aligned in CLUSTAL_X. The gammaproteobacterium Vibrio furnissii ATCC $35016^{\top}$ was used as the outgroup. Bootstrap values for 10000 replicates are shown. The tree was rendered in TREEVIEW (Page, 1996). Bar, 0.02 nucleotide substitutions per site.

Cells are motile, Gram-negative rods that are catalase- and oxidase-positive. Growth occurs in the presence of $13.5 \%$ $(\mathrm{w} / \mathrm{v}) \mathrm{NaCl}$. Bacteriochlorophyll $a$ is absent. Nitrate is reduced to nitrogen. The major fatty acid in cells grown at $30{ }^{\circ} \mathrm{C}$ is cis-11-octadecenoic acid $(18: 1 \omega 7 c)$. Comparative analysis of the nucleotide sequence of the 16S rRNA gene sequence indicates that the genus belongs in the $\alpha-2$ subclass of the Proteobacteria. The type species of the genus is Nesiotobacter exalbescens.

\section{Description of Nesiotobacter exalbescens sp. nov.}

Nesiotobacter exalbescens [ex.al.bes'cens. L. part. adj. exalbescens (from L. v. exalbesco) becoming white, growing white, referring to the fading colour of maturing colonies.]

Exhibits the following properties in addition to those given in the genus description. Circular colonies, beige, becoming off-white, translucent, flat to slightly raised, entire, smooth, glistening, $2-3 \mathrm{~mm}$ in diameter after $24 \mathrm{~h}$ at $30^{\circ} \mathrm{C}$ on MA. A pink hue that forms under a fresh culture on MA 2216E fades within $72 \mathrm{~h}$. Cells are $0 \cdot 4-0 \cdot 6 \mu \mathrm{m}$ wide by $1 \cdot 2-4 \mu \mathrm{m}$ long. Grows on TSA and in half-strength MB containing $0 \cdot 5-13.5 \%$ and $1-17 \cdot 5 \%(\mathrm{w} / \mathrm{v}) \mathrm{NaCl}$, respectively. Grows at $45^{\circ} \mathrm{C}$, but not at $50{ }^{\circ} \mathrm{C}$. Nitrate is reduced to nitrogen in the presence of $\mathrm{NaCl}$. $\beta$-Galactosidase is absent. Acid is produced from ribose, D-mannose, gluconate, D-fructose, D-glucose, methyl $\alpha$-D-glucoside and $\mathrm{N}$-acetylglucosamine in API $50 \mathrm{CHB} / \mathrm{E}$. Alkaline phosphatase, esterase $\left(\mathrm{C}_{4}\right)$, 
esterase lipase $\left(\mathrm{C}_{8}\right)$, leucine and cystine arylamidases and trypsin are expressed in API ZYM. The DNA G $+\mathrm{C}$ content is $61 \mathrm{~mol} \%$.

The type strain, $\mathrm{LA}_{33 \mathrm{~B}^{\mathrm{T}}}\left(=\right.$ ATCC BAA- $994^{\mathrm{T}}=\mathrm{CIP} 108449^{\mathrm{T}}$ ), was isolated from a hypersaline lagoon on Laysan Atoll in the Northwestern Hawaiian Islands.

\section{Acknowledgements}

This work was supported under NSF Microbial Observatories Program grant \#MCB0084326 to M. A. Thanks to the US Fish \& Wildlife Service and the Department of Land and Natural Resources for assistance. We are indebted to Dr Jim Maragos, Chief Scientist of the NOW-RAMP-II cruise. Thanks also to the captain and crew of the MV Rapture and NOW-RAMP-II participants. Field assistance was provided by Renee Harada. Kalle Johansson assisted in the laboratory and Tracey Freitas produced the phylogenetic tree. We are grateful to Dr Jean Euzéby for assistance with Latin grammar.

\section{References}

Altschul, S. F., Madden, T. L., Schäffer, A. A., Zhang, J., Zhang, Z., Miller, W. \& Lipman, D. J. (1997). Gapped BLAST and PSI-BLAST: a new generation of protein database search programs. Nucleic Acids Res 25, 3389-3402.

Atlas, R. M. (1997). Handbook of Microbiological Media, 2nd edn. Edited by L. C. Parks. Boca Raton, FL: CRC Press.

Bambauer, A., Rainey, F. A., Stackebrandt, E. \& Winter, J. (1998). Characterization of Aquamicrobium defluvii gen. nov., sp. nov., a thiophene-2-carboxylate-metabolizing bacterium from activated sludge. Arch Microbiol 169, 293-302.

de Lajudie, P., Willems, A., Pot, B. \& 7 other authors (1994). Polyphasic taxonomy of rhizobia: emendation of the genus Sinorhizobium and description of Sinorhizobium meliloti comb. nov., Sinorhizobium saheli sp. nov., and Sinorhizobium teranga sp. nov. Int J Syst Bacteriol 44, 715-733.

Donachie, S. P., Christenson, B. W., Kunkel, D. D., Malahoff, A. \& Alam, M. (2002). Microbial community in acidic hydrothermal waters of volcanically active White Island, New Zealand. Extremophiles 6, 419-425.

Donachie, S. P., Hou, S., Lee, K.-S. \& 11 other authors (2004a). The Hawaiian Archipelago: a microbial diversity hotspot. Microb Ecol 48, 509-520.

Donachie, S. P., Bowman, J. P. \& Alam, M. (2004b). Psychroflexus tropicus sp. nov., an obligately halophilic Cytophaga-FlavobacteriumBacteroides group bacterium from an Hawaiian hypersaline lake. Int J Syst Evol Microbiol 54, 935-940.

Fritsche, K., Auling, G., Andreesen, J. R. \& Lechner, U. (1999). Defluvibacter lusatiae gen. nov., sp. nov., a new chlorophenoldegrading member of the alpha-2 subgroup of proteobacteria. Syst Appl Microbiol 22, 197-204.

Hiraishi, A., Urata, K. \& Satoh, T. (1995). A new genus of marine budding phototrophic bacteria, Rhodobium gen. nov., which includes Rhodobium orientis sp. nov. and Rhodobium marinum comb. nov. Int J Syst Bacteriol 45, 226-234.
Lambert, B., Joos, H., Dierickx, S., VanTomme, R., Swings, J., Kersters, K. \& Van Montagu, M. (1990). Identification and plant interaction of a Phyllobacterium sp., a predominant rhizobacterium of young sugar beet plants. Appl Environ Microbiol 56, 1093-1102.

Lane, D. J. (1991). 16S/23S rRNA sequencing. In Nucleic Acid Techniques in Bacterial Systematics, pp. 115-175. Edited by E. Stackebrandt \& M. Goodfellow. Chichester: Wiley.

Maciolek, A. (1982). Lakes and lake-like waters of the Hawaiian Archipelago. Occ Pap Bernice P Bishop Mus 25, 1-14.

Marmur, J. (1961). A procedure for the isolation of deoxyribonucleic acid from microorganisms. J Mol Biol 3, 208-218.

Mergaert, J., Cnockaert, M. C. \& Swings, J. (2002). Phyllobacterium myrsinacearum (subjective synonym Phyllobacterium rubiacearum) emend. Int J Syst Evol Microbiol 52, 1821-1823.

Mesbah, M., Premachandran, U. \& Whitman, W. B. (1989). Precise measurement of the $\mathrm{G}+\mathrm{C}$ content of deoxyribonucleic acid by highperformance liquid chromatography. Int J Syst Bacteriol 39, 159-167.

Nishimura, Y., Muroga, Y., Saito, S., Shiba, T., Takayama, K. \& Shioi, Y. (1994). DNA relatedness and chemotaxonomic feature of aerobic bacteriochlorophyll-containing bacteria isolated from coasts of Australia. J Gen Appl Microbiol 40, 287-296.

Page, R. D. M. (1996). TreeView: an application to display phylogenetic trees on personal computers. Comput Appl Biosci 12, 357-358.

Rosson, R. A. \& Nealson, K. H. (1982). Manganese binding and oxidation by spores of a marine bacillus. J Bacteriol 151, 1027-1034.

Rüger, H.-J. \& Höfle, M. G. (1992). Marine star-shaped-aggregateforming bacteria: Agrobacterium atlanticum sp. nov.; Agrobacterium meteori sp. nov.; Agrobacterium ferrugineum sp. nov., nom. rev.; Agrobacterium gelatinovorum sp. nov., nom. rev.; and Agrobacterium stellulatum sp. nov., nom. rev. Int J Syst Bacteriol 42, 133-143.

Saitou, N. \& Nei, M. (1987). The neighbor-joining method: a new method for reconstructing phylogenetic trees. Mol Biol Evol 4, 406-425.

Sasser, M. (1997). Identification of Bacteria by Gas Chromatography of Cellular Fatty Acids. MIDI Technical Note 101. Newark, DE: MIDI, Inc.

Suzuki, T., Muroga, Y., Takahama, M. \& Nishimura, Y. (2000). Roseibium denhamense gen. nov., sp. nov. and Roseibium hamelinense sp. nov., aerobic bacteriochlorophyll-containing bacteria isolated from the east and west coasts of Australia. Int J Syst Evol Microbiol 50, 2151-2156.

Swings, J., Lambert, B., Kersters, K. \& Holmes, B. (1992). The genera Phyllobacterium and Ochrobactrum. In The Prokaryotes, 2nd edn, pp. 2601-2604. Edited by A. Balows, H. G. Trüper, M. Dworkin, W. Harder \& K. H. Schleifer. New York: Springer.

Uchino, Y., Hirata, A., Yokota, A. \& Sugiyama, J. (1998). Reclassification of marine Agrobacterium species: proposals of Stappia stellulata gen. nov., comb. nov., Stappia aggregata sp. nov., nom. rev., Ruegeria atlantica gen. nov., comb. nov., Ruegeria gelatinovora comb. nov., Ruegeria algicola comb. nov., and Ahrensia kieliense gen. nov., sp. nov., nom. rev. J Gen Appl Microbiol 44, 201-210.

Warner, R. E. (1963). Recent history and ecology of the Laysan duck. Condor 65, 3-23.

Wayne, L. G., Brenner, D. J., Colwell, R. R. \& 9 other authors (1987). International Committee on Systematic Bacteriology. Report of the ad hoc committee on reconciliation of approaches to bacterial systematics. Int J Syst Bacteriol 37, 463-464. 